\title{
Regulation Village Funds as Cash Direct Aid for Poor People in Rural Area due to Covid-19 Pandemic in Indonesia
}

\author{
Encik Muhammad Fauzan ${ }^{1}$, Yudi Widagdo Harimurti ${ }^{2}$, Indah Purbasari ${ }^{3}$, Indra \\ Yulianingsih ${ }^{4}$ \\ \{encik.fauzan@trunojoyo.ac.id ${ }^{1}$, yudi.harimurti@trunojoyo.ac.id², indah.purbasari@trunojoyo.ac.id ${ }^{3}$, \\ indra.yulianingsih@trunojoyo.ac.id $\left.{ }^{4}\right\}$ \\ Universitas Trunojoyo Madura, Indonesia ${ }^{1}$, Universitas Trunojoyo Madura, Indonesia ${ }^{2}$, Universitas \\ Trunojoyo Madura, Indonesia ${ }^{3}$, Universitas Trunojoyo Madura, Indonesia ${ }^{4}$
}

\begin{abstract}
The Covid-19 pandemic has impacted various aspects of life such as the global economy, especially for rural communities. The problem is how the Indonesian government policy in dealing with the impact of the Covid-19 outbreak toward people poverty in villages. Using doctrinal research that aims to find out government policies in handling Covid-19 for people in rural areas. Based on the results of this study, it was found that the handling of covid-19 for rural communities used village funds as direct cash aid for village communities. The local government must creat a regent regulation to distrubute cash direct aid from village funds toward people poverty villages.
\end{abstract}

Keywords: covid-19 pandemic, village funds, cash direct aid, regent regulation, rural communities

\section{Introduction}

World Health Organization (WHO) had declared the corona virus diseases (Covid-19) as a dangerous virus and a global pandemic. It significantly impact the global economic, political, and socio-culutral system. The measures and strategys to stop spread of the covid-19 have been carried out in ways such as keep the distance, trip and mobilitiy bans, society lockdown, stay at home campaign, self quarantine, and avoid the crowd [1]. The pandemic of Covid-19 influced all aspect in life who people feel could not their activities normally in long term.

It is difficult for us to predict when the Covid-19 pandemic outbreak will end and the long-term effects. Even though the community has had experience in dealing with several outbreaks in the past, it is still difficult to predict the social and economic conditions in the Covid-19 outbreak. Previous research has shown that when people are hit by disease outbreaks globally, people tend to keep their assets and are not interested in investing. It is a situation like this that results in changing people's behavior to protect and survive for themselves rather than thinking about what might happen in the future [2].

In response to the increasing transmission of Covid-19, many countries have banned social activities to prevent the spread of Covid-19. These countries have imposed border closures, restricted travel abroad, and postponed export and import activities of goods that are feared to trigger an economic crisis and recession in the future. The economic sector is a 
sector that has been severely affected by delays in raw material extraction, production of finished products and the closure of the service-providing industry [3].

Facing this difficult situation, the Indonesian government issued and provided several policies to prevent the expansion of the Covid-19 outbreak. These policies include large-scale social restrictions by closing schools, closing markets, shops, prohibiting group activities, encouraging work from home, and worshiping from home. The implementation of this largescale social restriction is enforced for 14 days and can be extended by looking at the situation and conditions of the development of Covid-19. This is because this virus can be transmitted through physical contact, namely touch, air and air and must maintain a distance between humans outside the room approximately 1.5 meters [4].

Indonesian Government has settled that Covid-19 is threat to Indonesia's economic could lead zero growth. Therefore, the government must solve immediately it, despite some people argue that the government to be slow in detecting a possible outbreak of this virus. This can be seen from the efforts of the government which previously even gave certain incentives so that the number of visits to Indonesia continues to increase in the middle of the Covid-19 pandemic [5]. The government has also attempted to provide incentives to the community such as direct cash assistance as cash incentives for the poor, especially in rural areas as people who have been directly affected by their socio-economics due to the Covid-19 pandemic. This research was conducted to describe how Indonesia government making models of regulation to coping rural community especially poverty people due to Covid-19 pandemic impacted. Therefore, the aim for the research to find out the model of Indonesian Government in coping rural community Covid-19 Impacted through its social public policy.

\section{Literature Review}

Village fund is a program from Indonesian Government as one of the financial instruments which will effectively alleviate poverty and reduce development gaps in local levels by strengthening development and empowering communities. This fund was allocated in national budgent and distribute to village goventment through its local government. The first allocation of villagge in 2015. Allocating of village fund using three methods namely percentage of central government revenue, common procedure like other expenditures, and formula [9].

Based on Government Regulation Number 60 Year 2014, the priority of village fund utilization is development and empowerment for rural community. In general, the use of village funds is prioritized to meet basic needs, develop local economic potential, and develop village infrastructure and facilities [10]. However in Covid-19 pandemic currently, the priority of village funds change to social aid of rural community.

The novel coronavirus disease (COVID-19) caused which caused by a strain of coronavirus (the SARS-CoV2) with begun in the city of Wuhan, Hubei province, China. This virus has had a long-term impact on human life globally. The virus that has spread by WHO was declared a global pandemic on March 11, 2020. Several studies have also shown that it may take more than a decade for the world to recover socially and economically or society can live a normal life [11]. 


\section{Methods}

Research type-This research was arranged by the using legal research methodology which focused on the doctrinal study. As a doctrinal research, the research was basically conducted by library study search to discover, explain, examine, principles, provisions, and concepts [6]. Doctrinal legal research makes abstract legal rules as a measure of truth in legal studies. The objects and references referred to in doctrinal research are the norms of norms, concepts and doctrines that develop in legal thinking [7].

Research Approach- Supporting doctrinal research, this study uses statute approach to analysis law deeply such as analysis the Indonesian government regulation in overcome community Covid-19 impacted. It means that the statutes used to answer the problem statement of the research refer to Indonesian government regulations enacted during the pandemic situation [8]

Material - Having declared that Indonesia was infected Covid-19 pandemic in March 2020, the President issued the Indonesia Government Regulation in lieu of laws Number 1 years 2020. Later, in May, this regulation is passed to Indonesian Law Number 2 Year 2020. They become the primary material. Besides, this research is supported by secondary material from article accessed in credible journals websites, books, official websites.

Method of Analysis- The collected materials are analyzed by using deductive reasoning. Deductive analysis derives from the general premise of the norm to be synchronized with the minor premise of the fact. The general premise regards to the concept, norm, or regulations of Indonesian government to cope with the impact of COVID-19 pandemic, as listed in the materials. Those laws will be examined to find the solution of coping Covid-19 impacted to rural community.

\section{Result and Discussion}

\subsection{Making Emergency Law and Using Village Fund}

The Indonesian government announced people infected with Covid-19 in March with 2 initial cases of people who were positive for Covid-19. This positive case continues to increase from week to week until August 2020. The increase in positive cases has had an impact on the Indonesian economy because the Indonesian government must impose largescale social restrictions, namely by reducing economic and social activities in the community. As a result, many companies have laid off workers because production cannot be maximized. This reduction in workforce has also resulted in increased unemployment and poverty, especially in rural areas. The Indonesian government in this condition has tried to accelerate state spending and divert the state budget for handling, preventing Covid-19 and overcoming the impact due to the implementation of this large-scale social restriction [12].

The first step when Indonesia was declared to be entering the Covid-19 pandemic, the government issued the Indonesian Regulation in Lieu (Government Regulation in Lieu of Law) Number 1 Year 2020. The regulation regulates the use of state finances for handling Covid-19, maintaining economic and financial stability due to the Covid-19. Meanwhile, the purpose of establishing the regulation, one of which is to provide a legal basis for the government in establishing policies and unusual steps due to the Covid-19 pandemic. This regulation has equal position with Indonesia law which passed by House of Representative. 
In Indonesian regulation system, there are types and hierarchies of laws. Refers to article 7 section 1 Indonesia Law Number 12 of 2011, stated that types and hierarchies of laws are:

1. The 1945 Indonesian Constitution,

2. MPR's Decree (People's Consultative Assembly/MPR or People Consultative Assembly)

3. Indonesian Law or government regulation in lieu of laws,

4. Government regulation,

5. Presidential regulation,

6. Provincial local laws,

7. Regency or municipality local laws.

The hierarcies of law above shows which regulations are under the law, on par with the legislation, and higher than legislation. Government regulations is a legal product which is the object of examination by the Parliament as an institution of the legislators because a maximum of 3 months after being issued by the government, the Government regulations must be discussed in the House of Representative. President issued the Government regulations by reason of the situation in matter of forcing as stipulated in article 22 the 1945 Indonesian Constitution. The article state This article states that the President could determine the Government regulations in urgent conditions and situations. This Government regulation is submitted to the House of Representatives for approval at the next session of the House of Representatives.

This constitution gives President a right to issue a Government regulation on condition that the critical compelling condition must base on the constitution. The provisions in this constitution reflect the importance when facing emergency condition such as the Cocid-19 outbreak [13]. The constitution as the basic law not only regulates the government system of a country, but there are particularly important social values, especially in coping the socioeconomic effect of the Covid-19 outbreak. It exists can be done through the Government regulations by allocating a state budget for handling the prevention of Covid-19 and its impacts. Therefore, Fauzan argues that the constitution also has two functions, namely a normative function and a sociological function. This normative function makes the constitution the main and first reference for the preparation of norms under it. While the sociological function means that this constitution has an important role in safeguarding and protecting the public against arbitrary actions by the government [14].

In accordance with the Verdict of the Constitutional Court Number 138 / PUUVII/2OO9, parameter in making Government regulations must include:

a. because of an urgent need to solve legal problem quickly according to the Act.

b. Law that is needed does not exist yet, so this happens the legal vacuum or the inadequacy of the current law there is, and

c. a legal vacuum that cannot be resolved in a way make laws in the usual procedure that requires quite a long time while the urgent situation need certainty to be completed.

Therefore, the Government regulations Number 1 Year 2020 is appropriate in recent situation where the covid-19 has caused all life aspect down. Government regulations could not create by President in every year like law. For this, in three months from issued by President. The Government regulations must passed by House of Representative. They could reject the Government regulations if the substance is not in accordance with people aspiration.

However, Government regulations Number 1 Year 2020 had passed by House of Representative through Indonesian Law Number 2 Year 2020. The Government regulations is a form of anticipation of the implications of the Covid-19 pandemic which will have an impact on slow up national economic growth, decreased state revenue but there is an increase in state spending and financing for save the country's health and economy. This Government 
regulation provides a change in state expenditure that has been previously determined into state expenditure that is focused on spending on health, social aid, and is used to restore the national economy. This economic recovery includes the affected business sector and communities. One of the substances of this Government regulation is the change in state financial policies related to budgeting and financing used for social safety nets with the use of budgets in village funds. Based on this Government regulation, the government refocuses village funds by adjusting the Village Fund budget ceiling. Furthermore, the village fund can be used for cash direct aid to the poor in villages and activities for handling the Covid-19 pandemic.

\subsection{Use of the Village Fund for poverty of rural community}

The village is the lowest jurisdiction unit in the government system in Indonesia. Villages can manage their villages through one government system, namely village government. The existence of this village is regulated in Indonesian Law Number 6 of 2014 on Villages where the Law functions to contain all the concern and necessity of village communities, which until now around 73,000 villages in Indonesia. This means that most Indonesians live in rural areas. This law does not only provide protection for the existence of villages, but there is an even more important aspect than just the existence of this law, namely the government provides opportunities for village development with the existence of a village fund budget. This aspect has been further informed in Government Regulation Number 43 Year 2014. The concepts of this Law of Village to be independent to solve village problems, build facilities according to budget, increase community participation, carry out development planning, improve the quality of human resources of village officials, carry out social activities and services to the community [15].

The Village Fund is a fund sourced from the state budget allocated to village governments through the district/city regional revenue and expenditure budget. This village fund is used to finance governance, implementation of infrastructure development, community development, and community empowerment. To provide a legal basis for the existence of this village fund, government regulation number 60 of 2014 has been prepared. This regulation is an implementing regulation of Law Number 6 of 2014 concerning Villages. The existence of this regulation is so that the implementation of village government can run village governance well, there is legal certainty, orderly governance, openness, professionalism, accountability, effectiveness, and efficiency, maintaining local wisdom, diversity, and participation. Thus, in implementing village development, the priority is the value of togetherness, kinship, and cooperation to achieve peace and social justice [16].

The implementation of village development to run according to development principles in the village, the village government must prepare a medium-term development plan and a village government work plan. This development planning can be financed from the village fund budget by looking at the situation, conditions and needs of the village. The importance of village funds for villages and village communities, so the use of village funds must be aimed at increasing village development and the welfare of village communities. Village communities are part of the Indonesian community in the smallest area [17].

The allocation of village funds is further regulated in the regulation of the village minister, development of underdeveloped areas and transmigration number 11 Year 2019. Derive from this regulation, the priority of using village funds is used to finance various 
village programs and activities that must provide benefits to village communities such as improving the quality of life, increasing welfare, poverty alleviation and community services.. This regulation also emphasizes the use of village funds for natural disaster preparedness, natural disaster management, and environmental conservation.

However, with the covid-19 pandemic, the ministerial regulation was changed through ministerial regulations number 6 and number 7 Year 2020. The amendments were made because the transmission of Covid-19 has had an influence on social, economic, and welfare of the people of the Village. In addition, in the Government regulations Number 1 of 2020 as stipulated by Law Number 2 of 2020, the use of Village Funds can be used for direct cash assistance to the poor in the village. The ministerial regulation regulates the amount of direct cash assistance to the rural poor. Direct cash assistance was given for 6 months, where in the first 3 months the community received 600 thousand per month and in the next 3 months received 300 thousand per month. The cash direct aid could be distributed by villages if the village funds for a village are still available. This means that village funds which were originally for village development, due to the conditions of the Covid-19 pandemic, were used to maintain the economic stability of rural communities. The Covid-19 pandemic has eliminated the jobs of poor families in villages. They cannot work or lose their jobs and must stay at home to prevent the spread of this virus.

\subsection{Cash Direct Aid distribution}

The distribution of direct cash assistance from the Village Fund budget must be carried out by the regional government through the formation of a regent regulation. This district head regulation regulates how village heads can distribute direct cash assistance to the community. Without this regent's regulation, cash direct aid would not be given to those entitled to receive it. Therefore, the position of district head regulations as a product of regional law is important as a technical regulation. This regulation is created by head of local government. Making the regent regulation to avoid legal vacancy and the substance derive from the local laws and or the enactment of the minister [18].

The regent's regulation regarding the distribution of direct cash assistance can be specially formed or make changes to the existing regent regulations regarding the distribution of village funds. The formation of this regent regulation does not only refer to the enactment of the minister of villages, underdeveloped region and transmigration, it must also refer to the enactment of the minister of finance such as the regulation of the minister of finance number 40/PMK.07/2020, the regulation of the minister of finance number 50/ PMK.07/2020 regarding amendment of the enactment of the minister of finance number 205/PMK.07 /2019 about the management of village funds.

The management of village funds must indeed refer to two different ministries. The ministry of villages, underdeveloped regions and transmigration regulates general policy priorities for the use of village funds while the ministry of finance regulates the mechanism for transferring village funds to regional finances and documents for financial accountability. The existence of the regent's regulation serves as a guideline for channeling village funds as direct cash assistance to poor rural communities affected by Covid-19. 


\section{Conclusion}

Facing the covid-19 pandemic situation, Indonesian government policies are needed in maintaining the socio-economic stability of the community. Indonesian people who live in rural areas have become residents affected by the Covid-19 pandemic because they have lost income due to social restrictions to prevent more widespread transmission. Therefore, the government has enacted Indonsian law number 2 year 2020 concerning stipulation of government regulations in lieu of law number 1 year 2020. The law provides an order, one of which is the use of the Village Fund budget to be used as cash direct aid as a form of handling the impact of Covid-19 on poor people of rural communities. Village funds which should have been used for village development, during the Covid-19 pandemic, were used as a solution to ease the burden on rural communities. The implementation and realization of village funds must be carried out through the formation of a regent regulation as the legal basis for disbursing village funds because it will definitely change the regent's regulations regarding the allocation of village funds which must be re-allocated in the form of cash direct aid to maintain the economy of rural communities.

\section{References}

[1] M. Sigala, "Tourism and COVID-19: Impacts and implications for advancing and resetting industry and research," J. Bus. Res., vol. 117, no. June, pp. 312-321, 2020, doi: 10.1016/j.jbusres.2020.06.015.

[2] N. Donthu and A. Gustafsson, "Effects of COVID-19 on business and research," J. Bus. Res., vol. 117, no. June, pp. 284-289, 2020, doi: 10.1016/j.jbusres.2020.06.008.

[3] M. Nicola et al., "The socio-economic implications of the coronavirus pandemic (COVID-19): A review," Int. J. Surg., vol. 78, no. March, pp. 185-193, 2020, doi: 10.1016/j.ijsu.2020.04.018.

[4] Zaharah, G. I. Kirilova, and Anissa Windarti, "Impact of Corona Virus Outbreak Towards Teaching and Learning Activities in Indonesia,” Salam; J. Sos. Budaya Syar-i, vol. 7, no. 3, pp. 269-282, 2020, doi: 10.15408/sjsbs.v7i3.15104.

[5] M. Hidayaturrahman and E. Purwanto, "COVID-19: Public support to handle economic challenges," J. Inov. Ekon., 2020, doi: 10.22219/jiko.v5i3.11681.

[6] A. Yaqin, Legal Research and Writing. Kelana Jaya Selangor: Lexis Nexis, 2007.

[7] M. H. Hakim, "PERGESERAN ORIENTASI PENELITIAN HUKUM: DARI DOKTRINAL KE SOSIO-LEGAL," Syariah J. Huk. dan Pemikir., vol. 16, no. 2, p. 105, 2017, doi: 10.18592/sy.v16i2.1031.

[8] K. Benuf and M. Azhar, "Metodologi Penelitian Hukum sebagai Instrumen Mengurai Permasalahan Hukum Kontemporer," Gema Keadilan, vol. 7, no. 1, pp. 20-33, 2020.

[9] M. Paellorisky and A. Solikin, "Village Fund Reform: A Proposal for More Equitable Allocation Formula," J. Bina Praja, no. 21, pp. 1-13, 2019, doi: 10.21787/jbp.11.2019.1-13.

[10] I. Meutia and L. Liliana, "The Management of Village Fund Finances," J. Din. Akunt., vol. 9, no. 1, pp. 63-81, 2018, doi: 10.15294/jda.v9i1.12009.

[11] R. Djalante et al., "Review and analysis of current responses to COVID-19 in Indonesia: Period of January to March 2020," Prog. Disaster Sci., vol. 6, p. 100091, 2020, doi: 10.1016/j.pdisas.2020.100091.

[12] S. Susilawati, R. Falefi, and A. Purwoko, "Impact of COVID-19's Pandemic on the Economy of Indonesia," Budapest Int. Res. Critics Inst. Humanit. Soc. Sci., vol. 3, no. 2, pp. 1147-1156, 2020, doi: 10.33258/birci.v3i2.954.

[13] E. M. Fauzan, "Evaluasi Pentingnya Perpu Dalam Peraturan Perundang-Undangan Dan Ketatanegaraan Indonesia," in Sipendikum, 2018, pp. 184-199. 
[14] E. M. Fauzan, "Fungsi Sosiologis Undang-Undang Dasar Negara Republik Indonesia Tahun 1945 dalam Memenuhi Hak-Hak Masyarakat,” Masal. Huk. J., vol. 42, no. 3, pp. 346-354, 2013, doi: 10.14710/mmh.42.3.2013.346-355.

[15] A. Widiyanti, "Implementation of Local Participation as Part of Good Governance Principles: Galengdowo Village Wonosalam Sub-District, Jombang," J. Akunt. dan Keuang., vol. 19, no. 2, pp. 59-66, 2017, doi: 10.9744/jak.19.2.59-66.

[16] F. A. Nasution, Erlina, and Rujiman, "The Role of Village Funds to the Development Area in the Sub- District of West Bilah, Labuhanbatu Regency, North Sumatera, Indonesia," Int. J. Progress. Sci. Technol., vol. 6, no. 1, pp. 221-227, 2017.

[17] H. M. Syafingi, D. A. S. Dewi, Suharso, Heniyatun, P. Sulistyaningsih, and U. Rahmawati, "Village fund optimization strategy for rural community welfare in Indonesia," J. Crit. Rev., vol. 7, no. 7, pp. 580-583, 2020, doi: 10.31838/jcr.07.07.103.

[18] Y. W. H. E. M. F. I. Y. I. Purbasari, "Consensus as Democratic Education on the Village Consultative Body Election in Bangkalan," vol. 11, no. 2, pp. 84-110, 2020, [Online]. Available: https://jsser.org/index.php/jsser/article/download/2020/448. 